\title{
A comparison of detomidine in combination with saline, morphine or methadone in horses submitted to experimental oral stimuli
}

\section{Comparação entre a associação da detomidina à solução salina, à morfina ou à metadona em cavalos submetidos aos estímulos experimentais na cavidade oral}

\author{
Rafael Costa Guilhen ${ }^{1}$; Renata Navarro Cassu ${ }^{1 *}$; Miriely Steim Diniz ; \\ Rogério Giuffrida ${ }^{1}$; Rodrigo Rolim Duarte $^{3}$
}

\begin{abstract}
This study aimed to compare the sedative and cardiopulmonary effects of detomidine in combination with saline, morphine or methadone and to determine whether the addition of these opioids increases the degree of sedation in horses submitted to experimental oral stimuli. In a blinded, randomized, experimental study, six adult mares were evaluated using a crossover design with at least 15 days between trials: $10 \mu \mathrm{g} / \mathrm{kg}$ detomidine in combination with saline $(\mathrm{D} / \mathrm{SAL}), 0.1 \mathrm{mg} / \mathrm{kg}$ morphine $(\mathrm{D} /$ $\mathrm{MORPH})$ or $0.1 \mathrm{mg} / \mathrm{kg}$ methadone (D/METH). The degree of sedation, response to oral stimuli and cardiopulmonary parameters were monitored for 120 minutes. Parametric data were analyzed using the ANOVA and Tukey's tests, and non- parametric data were analyzed with the Kruskal-Wallis and Friedman's tests with the post-Dunn test $(\mathrm{P}<0.05)$. The degree of sedation was significantly greater for the D/SAL than for the D/MORPH and D/METH treatments at $30 \mathrm{~min}$. The horses' responses to the oral stimuli decreased significantly following all treatments at 5 and $30 \mathrm{~min}$ from baseline values. The heart rate, respiratory rate, arterial $\mathrm{pH}$ and blood gas variables were all similar among the treatment groups. Mean arterial blood pressure was significantly higher in the D/MORPH group when compared with the D/SAL group between 75 and 120 min. It was concluded that all treatments provided sedative effects with mild cardiopulmonary changes. However the addition of morphine or methadone to detomidine did not improve the degree of sedation in horses submitted to experimental oral stimuli.
\end{abstract}

Key words: Alpha 2 adrenoreceptor agonists, dental, equine, opioids

\section{Resumo}

Objetivou-se comparar os efeitos sedativos e cardiorrespiratórios da detomidina associada à solução salina, à morfina ou à metadona e determinar se a associação desses opioides poderia incrementar o grau de sedação em cavalos submetidos aos estímulos na cavidade oral. Em estudo cego, com delineamento aleatório foram avaliadas 06 éguas, com intervalo mínimo de 15 dias entre cada avaliação, sendo submetidos aos protocolos de sedação com detomidina $(10 \mu \mathrm{g} / \mathrm{kg}$, IV) associada à solução salina (D/SAL), a $0,1 \mathrm{mg} / \mathrm{kg}$ (IV) de morfina (D/MORF) ou a $0,1 \mathrm{mg} / \mathrm{kg}$ (IV) de metadona (D/MET). Foram avaliados, durante 120 minutos: grau de sedação, resposta aos estímulos orais e parâmetros cardiorrespiratórios. A estatística foi realizada com análise de variância, teste de Tukey e análise de

\footnotetext{
${ }^{1}$ Profs., Universidade do Oeste Paulista, UNOESTE, Presidente Prudente, SP, Brasil. E-mail: guilhen@unoeste.br; navarro@ unoeste.br; rgiuffrida@unoeste.br

2 Discente, Universidade Estadual Paulista, UNESP, Botucatu, SP, Brasil. E-mail: mirielysd@yahoo.com.br

3 Prof., Centro Universitário de Maringá, CESUMAR, Maringá, PR, Brasil. E-mail: rolimvet@yahoo.com.br

* Author for correspondence
} 
medidas repetidas, para as variáveis paramétricas. Para as variáveis não paramétricas foram empregados os testes de Kruskal-Wallis e de Friedman com contrastes pelo método de Dunn $(\mathrm{P}<0,05)$. O efeito sedativo foi significativamente superior no D/SAL em relação ao D/MORF e D/MET aos 30 minutos após a administração dos fármacos. A resposta dos animais perante os estímulos feitos na cavidade oral diminuiu significativamente aos 5 e 30 minutos em relação ao basal em todos os tratamentos. A frequência cardíaca e respiratória, bem como as variáveis hemogasométricas não diferiram entre os grupos. Valores superiores de pressão arterial foram observados no grupo D/MORF em relação ao D/ SAL dos 75 aos 120 minutos. Conclui-se que os três tratamentos determinaram discretas alterações nos parâmetros cardiorrespiratórios, além de efeito sedativo. Contudo, a adição dos opioides à detomidina não incrementou o grau de sedação em cavalos submetidos aos estímulos na cavidade oral.

Palavras-chave: Adrenorreceptores agonistas $\alpha_{2}$, opioides, odontologia, equino

\section{Introduction}

Sedatives and analgesics have been widely used for diagnostic procedures and minor surgeries in equine practice (FREEMAN; ENGLAND, 2000). The most commonly used drugs are the alpha $_{2}$ adrenoreceptor agonists ( $\alpha_{2}$-agonists); detomidine, xylazine and romifidine, and their sedative and analgesic effects are extensively described in the literature (NANNARONE et al., 2007; ROHRBACH et al., 2009; VALVERDE, 2010). However, due to the insufficient stability of sedation and the short period of action, it is common to combine $\alpha_{2}$-agonists with other drugs, principally opioids, to induce neuroleptanalgesic effects that result in a better degree of sedation/analgesia and more prolonged effects (CLARKE; PATON, 1988; SOLANO et al., 2009).

Nevertheless, administration of opioids to healthy, pain-free horses may cause sympathetic stimulation and central nervous system excitation (LOVE et al., 2011). These effects are dose- related and the administration of a sedative drug before the opioid is thought to decrease the extent of their expression (CORLETTO et al., 2005).

Several trials have reported the clinical effects of opioids, mainly, morphine, buthorphanol and buprenorphine, in combination with $\alpha_{2}$-agonists in equine practice, including ophthalmologic procedures (ROBERTSON, 2004) and minor surgeries in standing horses (VAN DIJK et al., 2003; SOLANO et al., 2009; BENREDOUANE et al., 2011) However, there is little information in the current literature regarding these drug combinations for equine dental practice.

The aims of this study were to compare the sedative and cardiopulmonary effects of detomidine in combination with saline, morphine and methadone and to determine whether the addition of these opioids increases the degree of sedation in horses submitted to experimental oral stimuli.

\section{Materials and Methods}

\section{Animals}

Six mixed breed adult mares, weighing between 250 and $380 \mathrm{~kg}$ and aged from 4 to 12 years, were used in this study. The right carotid artery of the mares was surgically repositioned to a subcutaneous location under general anesthesia at least one month prior to the study. The horses were assessed as healthy based on physical examination and a complete blood count. The study was approved by the Ethics in Animal Research Institutional Committee (Protocol number 060/2009).

\section{Experimental design}

Prior to the experiment, the horses were placed in stocks and allowed 20 min to acclimatize to their surroundings. The horses were randomly assigned to receive all of the following three intravenous treatments, at 15 day intervals, in a double-blind 
design: the control group (D/SAL) received $10 \mu \mathrm{g} /$ kg detomidine (Dormiun V, Agener União Animal Health, SP, Brazil) and saline, the morphine group (D/MORPH) received $10 \mu \mathrm{g} / \mathrm{kg}$ detomidine and $0.1 \mathrm{mg} / \mathrm{kg}$ morphine (Dimorf, Cristália Chemical and Pharmaceutical Products Ltda, SP, Brazil), and the methadone group (D/METH) received $10 \mu \mathrm{g} / \mathrm{kg}$ detomidine and $0.1 \mathrm{mg} / \mathrm{kg}$ methadone (Metadon, Cristália Chemical and Pharmaceutical Products Ltda, SP, Brazil). To preserve blinding, all treatments had a final volume of $10 \mathrm{~mL}$. Thus, both opioids were diluted to a final volume of $10 \mathrm{~mL}$ in saline and were administered after the detomidine injection. In the D/SAL treatment, $10 \mathrm{~mL}$ of 0.9 per cent saline was administered after the detomidine injection. A 16-gauge catheter was placed in the right jugular vein to facilitate injection of the drugs, which were administered over a period of 60 seconds.

Evaluation of sedative effects and behavioral response to oral stimulus

The degree of sedation was quantified using the following criteria: labial ptosis (absent $=0$ or present $=1$ ), palpebral ptosis (absent $=0$ or present $=1$ ) and degree of ataxia (normal body posture $=0$; leans slightly on stocks $=1$; leans strongly on stocks $=2$; difficulty standing=3) (BRYANT et al., 1991; ROHRBACH et al., 2009).

Furthermore, the degree of sedation was indirectly assessed by measuring the distance from the lower lip to the ground, in centimeters, using a ruler fixed to the wall near the animal's head. The percentage change in head droop was used as an indicator of the depth of sedation as described by Kaukinen et al. (2011). The onset of sedation was considered as the moment when the head droop was more than $20 \%$ and the horse appeared to be clinically sedated. The end of sedation was considered as the moment when the head droop returned to the pre-administration level.
The behavioral reaction to oral stimuli was evaluated as described by Roscoe (2007). The reaction was measured by injecting $20 \mathrm{~mL}$ of water under pressure into the middle third of the oral cavity using a needleless syringe, and during dental floating using an electric burr (Ortovet, Brazil) which rotated at high-speed and was applied to the buccal aspect of the teeth, using the modified Triadan system, for at least 15 seconds. Furthermore, the response was assessed via pinprick with a 24-gauge 0.55 inch needle on the gingival pocket parallel to the teeth (ROSCOE, 2007), according to the following sequence: first incisor, upper right; first incisor, upper left; second incisor, upper right; and second incisor, upper left.

The response to oral stimuli was scored on a 5-point scale as follows: $0=$ no response; $1=$ movement of tongue; $2=$ movement of tongue and/or upper lip; $3=$ movement of tongue and/ or upper lip and head; 4=escape from stimulus (ROSCOE, 2007). The sum of the scores of all of the criteria was used for data analysis. Thus, the total score at each observation interval (sum of the applied oral stimuli, including: water instilling [04], dental float insertion [0-4] and pinprick on the gingival pocket [0-4]) could vary from 0 to 12 .

Measurements were performed before and at 5, 30, 60, 90 and 120 min after IV drug injection by a single investigator who was blinded to the treatments throughout the experiment.

\section{Evaluation of cardiopulmonary and hemogasometric effects}

An 18-gauge catheter was introduced aseptically into the right carotid artery for systemic arterial blood pressure measurements and the collection of arterial blood. Mean arterial blood pressure (MAP) was measured using aneroid manometer (Becton Dickinson, Brazil). Heart rate (HR) and rhythm were monitored by auscultating the heart from the 
left side of the horse at the level of the ulnar process for $1 \mathrm{~min}$, using a stethoscope (Becton Dickinson, Brazil). Respiratory rate (RR) was measured through observation of thoracic movements for one minute. MAP, HR and RR measurements were performed immediately before, 5 mins after, and every following 15 mins for 120 mins after IV injection of the treatments.

Arterial blood gas samples were collected in heparinized syringes from the catheter in the carotid artery and analyzed immediately in an automated blood gas analyzer (Cobasp, model 121, RocheMacromed, Brazil). The samples were corrected for body temperature. Arterial $\mathrm{pH}$, carbon dioxide partial pressure $\left(\mathrm{PaCO}_{2}\right)$, oxygen partial pressure $\left(\mathrm{PaO}_{2}\right)$, arterial hemoglobin saturation $\left(\mathrm{SaO}_{2}\right)$, arterial bicarbonate concentration $\left(\mathrm{HCO}_{3}\right)$ and base excess (BE) were determined immediately before and at 5, 15, 30, 60, 90 and 120 min after IV injection of the treatments.

Observations were performed by the same person and in the same order (heart rate, respiratory rate, arterial blood pressure, arterial blood sample collection, labial and palpebral ptosis, ataxia, head height and responses to oral stimuli).

\section{Statistical analysis}

A Kolmogorov-Smirnov-test was performed to assess normality of the variables. Values for HR, RR, MAP, $\mathrm{PaCO}_{2}, \mathrm{PaO}_{2}$, arterial $\mathrm{pH}, \mathrm{HCO}_{3}^{-}$and percentage change in the head droop were analyzed using a two-way analysis of variance (ANOVA) followed by a Tukey test to compare differences between treatment groups at each time point and differences in time for each treatment group. The degree of sedation and response to oral stimuli were compared at different time-points by means of a nonparametric Friedman test for repeated measures. For comparisons at each time point a nonparametric Kruskal-Wallis test followed by a post-hoc Dunn's test were employed. All analyses were performed using the computer software (GraphPad Instat5). Differences were considered significant when $\mathrm{P}<0.05$.

\section{Results}

The degree of ataxia and labial and palpebral ptosis were similar among the treatment groups. All the horses developed moderate hind limb ataxia (score 2) during the first 30 mins after drug injection. This was accompanied by labial and palpebral ptosis.

The percentage change in the head droop was significantly greater for the $\mathrm{D} / \mathrm{SAL}$ treatment than the D/MORPH and D/METH treatments at $5 \mathrm{~min}(\mathrm{P}$ $=0.0123)$ and at $30 \mathrm{~min}(\mathrm{P}=0.0013)$. The greatest mean head droop ( $70 \%$ from baseline) was observed after $5 \mathrm{~min}$ for the D/SAL treatment group. For the D/MORPH and D/METH treatments, the deepest head droop (44.2\% and 40.8\%, respectively) occurred 5 min after injection of the drug. Compared with baseline values, higher sedation levels were observed until $90 \mathrm{~min}, 60 \mathrm{~min}$ and $30 \mathrm{~min}$ after the drug injection for the D/SAL, D/METH, and $\mathrm{D} / \mathrm{MORPH}$ treatment groups, respectively $(\mathrm{P}<$ 0.0001 ) (Figure 1). The median duration of sedation was $66 \pm 25,50 \pm 12$ and $66 \pm 10 \mathrm{~min}$ for the D/ SAL, D/MORPH and D/METH treatment groups, respectively. 
Figure 1. Mean $\pm \mathrm{SD}$ of head droop (\%) in horses treated with detomidine in combination with saline (D/SAL), morphine (D/MORPH) or methadone (D/METH).

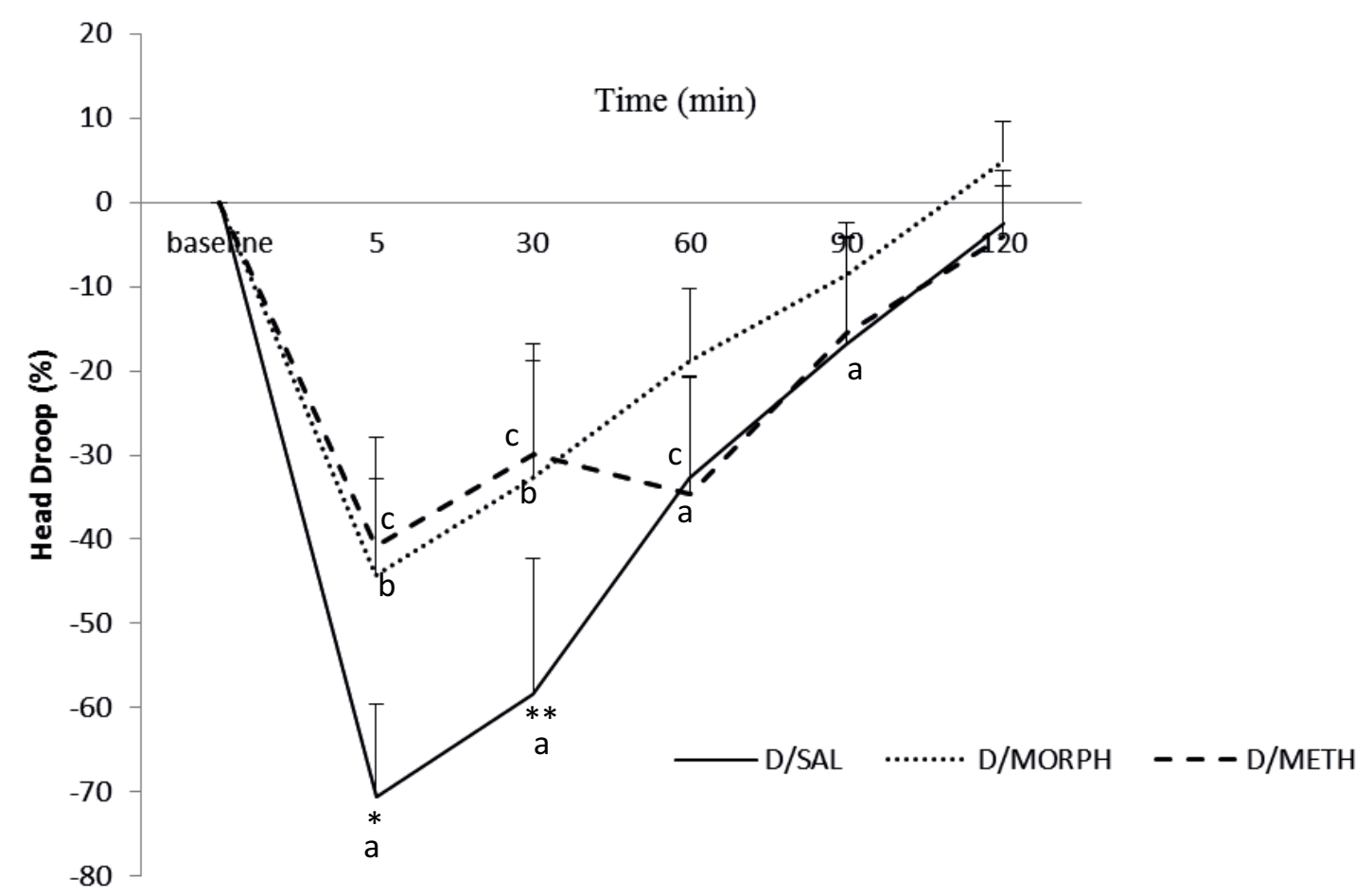

Note: *D/SAL significantly different from D/MORPH and D/METH groups $(\mathrm{P}=0.0123)$. **D/SAL significantly different from $\mathrm{D} / \mathrm{MORPH}$ and $\mathrm{D} / \mathrm{METH}$ groups $(\mathrm{P}=0.0013)$. ${ }^{a}$ Significantly different from baseline for $\mathrm{D} / \mathrm{SAL}$ group. ( $\mathrm{P}<0.0001)$. ${ }^{\mathrm{b}}$ Significantly different from baseline for $\mathrm{D} / \mathrm{MORPH}$ group $(\mathrm{P}<0.0001)$. ${ }^{\mathrm{c}}$ Significantly different from baseline for D/METH group $(\mathrm{P}<0.0001)$. ANOVA followed by post-test with Tukey- Kramer Multiple Comparisons Test.

The sum of the oral scores decreased significantly $(\mathrm{P}<0.05)$, following all treatments, between the 5 and $30 \mathrm{~min}$ from baseline values (Figure 2). There were no significant differences among the treatment groups.

There were no significant differences in HR, RR, $\mathrm{PaCO}_{2}, \mathrm{PaO}_{2}$, arterial $\mathrm{pH}$ or $\mathrm{HCO}_{3}{ }^{-}$among treatments (Tables 1 and 2). Compared with baseline, HR decreased significantly at $5 \mathrm{~min}$ after detomidine/ saline administration $(\mathrm{P}=0.0084)$. While no changes were observed for MAP over time, after detomidine/ saline and detomidine/methadone injection, MAP values were significantly increased from baseline between 90 to $120 \mathrm{~min}$ after detomidine/morphine administration $(\mathrm{P}<0.0001)$. In addition, MAP values were significantly higher in the D/MORPH group when compared with D/SAL group between 75 and $120 \mathrm{~min}$ (Table 1).

Muscle tremors were observed in two of the six morphine treated horses between 75 and 120 mins; these signs persisted for around four hours after the end of the study. Additionally, one of these horses showed behavioral signs of excitement 120 mins after drug injection. 
Figure 2. Sum of oral scores (median and lower-upper range) in horses treated with detomidine in combination with saline (D/SAL), morphine (D/MORPH) or methadone (D/METH).

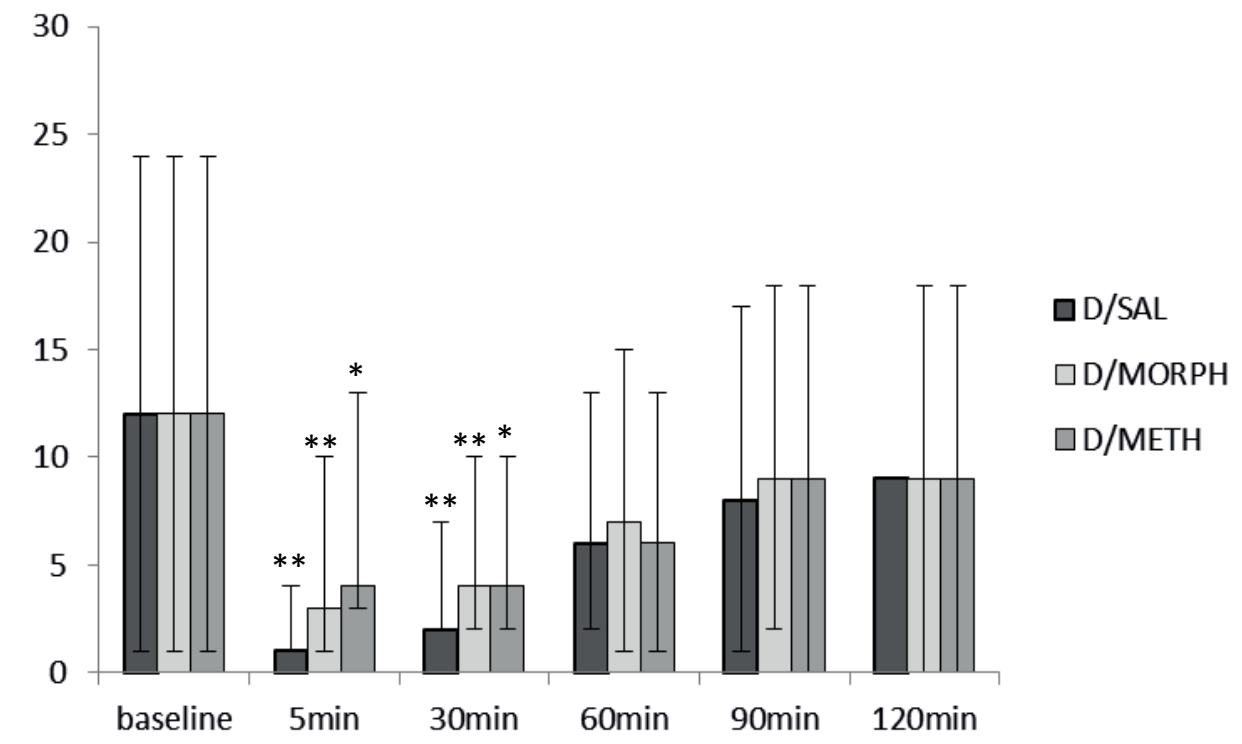

Note: Comparisons over time within each group (Friedman test). *Significantly different from baseline values $(\mathrm{P}=0.005)$. $* *$ Significantly different from baseline values $(\mathrm{P}=0.002)$.

Table 1. Heart rate (HR), respiratory rate (RR) and mean arterial blood pressure (MAP) measured before treatment (ie, basal), 5, 15, 30, 45, 60, 75, 90, 105 and 120 minutes after treatment with detomidine in combination with saline (D/SAL), morphine (D/MORPH) or methadone (D/METH) in horses.

\begin{tabular}{lccccccccc}
\hline & \multicolumn{3}{c}{ HR (beats/min) } & \multicolumn{3}{c}{ RR (breaths/min) } & \multicolumn{3}{c}{ MAP $(m m H g$} \\
\hline Time & D/SAL & D/MORPH & D/METH & D/SAL & D/MORPH & D/METH & D/SAL & D/MORPH & D/METH \\
\hline basal & $36 \pm 5^{\mathrm{aA}}$ & $35 \pm 5^{\mathrm{aA}}$ & $35 \pm 3^{\mathrm{aA}}$ & $18 \pm 5^{\mathrm{aA}}$ & $15 \pm 3^{\mathrm{aA}}$ & $16 \pm 4^{\mathrm{aA}}$ & $95 \pm 13^{\mathrm{aA}}$ & $98 \pm 8^{\mathrm{aA}}$ & $104 \pm 1^{\mathrm{aA}}$ \\
5 & $30 \pm 5^{\mathrm{bA}}$ & $32 \pm 5^{\mathrm{aA}}$ & $33 \pm 6^{\mathrm{aA}}$ & $16 \pm 3^{\mathrm{abA}}$ & $13 \pm 2^{\mathrm{aA}}$ & $12 \pm 2^{\mathrm{abA}}$ & $108 \pm 3^{\mathrm{aA}}$ & $109 \pm 13^{\mathrm{abA}}$ & $115 \pm 5^{\mathrm{aA}}$ \\
15 & $31 \pm 5^{\mathrm{abA}}$ & $32 \pm 3^{\mathrm{aA}}$ & $32 \pm 7^{\mathrm{aA}}$ & $15 \pm 1^{\mathrm{abA}}$ & $15 \pm 4^{\mathrm{aA}}$ & $11 \pm 2^{\mathrm{bA}}$ & $108 \pm 4^{\mathrm{aA}}$ & $101 \pm 16^{\mathrm{abA}}$ & $108 \pm 10^{\mathrm{aA}}$ \\
30 & $32 \pm 5^{\mathrm{abA}}$ & $33 \pm 3^{\mathrm{aA}}$ & $33 \pm 4^{\mathrm{aA}}$ & $14 \pm 3^{\mathrm{abA}}$ & $12 \pm 3^{\mathrm{aA}}$ & $15 \pm 3^{\mathrm{abA}}$ & $107 \pm 2^{\mathrm{aA}}$ & $99 \pm 11^{\mathrm{abA}}$ & $112 \pm 9^{\mathrm{aA}}$ \\
45 & $31 \pm 4^{\mathrm{abA}}$ & $33 \pm 4^{\mathrm{aA}}$ & $31 \pm 6^{\mathrm{aA}}$ & $12 \pm 1^{\mathrm{bA}}$ & $13 \pm 5^{\mathrm{aA}}$ & $13 \pm 1^{\mathrm{abA}}$ & $103 \pm 5^{\mathrm{aA}}$ & $107 \pm 7^{\mathrm{abA}}$ & $109 \pm 16^{\mathrm{aA}}$ \\
60 & $34 \pm 3^{\mathrm{abA}}$ & $37 \pm 4^{\mathrm{aA}}$ & $36 \pm 4^{\mathrm{aA}}$ & $12 \pm 1^{\mathrm{bA}}$ & $14 \pm 5^{\mathrm{aA}}$ & $13 \pm 2^{\mathrm{abA}}$ & $96 \pm 13^{\mathrm{aA}}$ & $105 \pm 7^{\mathrm{abA}}$ & $95 \pm 19^{\mathrm{aA}}$ \\
75 & $33 \pm 3^{\mathrm{abA}}$ & $35 \pm 4^{\mathrm{aA}}$ & $35 \pm 4^{\mathrm{aA}}$ & $13 \pm 1^{\mathrm{bA}}$ & $15 \pm 4^{\mathrm{aA}}$ & $13 \pm 3^{\mathrm{abA}}$ & $90 \pm 18^{\mathrm{aA}}$ & $114 \pm 8^{\mathrm{abB}}$ & $99 \pm 13^{\mathrm{aAB}}$ \\
90 & $34 \pm 5^{\mathrm{abA}}$ & $38 \pm 5^{\mathrm{aA}}$ & $32 \pm 3^{\mathrm{aA}}$ & $13 \pm 2^{\mathrm{bA}}$ & $15 \pm 3^{\mathrm{aA}}$ & $15 \pm 3^{\mathrm{abA}}$ & $86 \pm 11^{\mathrm{aA}}$ & $117 \pm 11^{\mathrm{bB}}$ & $102 \pm 7^{\mathrm{aAB}}$ \\
105 & $33 \pm 4^{\mathrm{aAA}}$ & $38 \pm 4^{\mathrm{aA}}$ & $33 \pm 5^{\mathrm{aA}}$ & $13 \pm 3^{\mathrm{bA}}$ & $16 \pm 6^{\mathrm{aA}}$ & $13 \pm 2^{\mathrm{abA}}$ & $85 \pm 6^{\mathrm{aA}}$ & $115 \pm 4^{\mathrm{bB}}$ & $104 \pm 6^{\mathrm{aAB}}$ \\
120 & $34 \pm 5^{\mathrm{abA}}$ & $37 \pm 4^{\mathrm{aA}}$ & $32 \pm 5^{\mathrm{aA}}$ & $12 \pm 1^{\mathrm{bA}}$ & $13 \pm 3^{\mathrm{aA}}$ & $14 \pm 1^{\mathrm{abA}}$ & $82 \pm 3^{\mathrm{aA}}$ & $119 \pm 1^{\mathrm{bB}}$ & $101 \pm 9^{\mathrm{aAB}}$ \\
\hline
\end{tabular}

Note: Data are expressed as mean \pm standard deviation (SD). Different small letters in the same column indicate statistical difference over time within each group. Different capital letters in the same line indicate statistical difference among the groups. ANOVA with post-test Tukey-Kramer Multiple Comparisons Test $(\mathrm{P}<0.05)$. 
Table 2. Carbon dioxide partial pressure $\left(\mathrm{PaCO}_{2}\right)$, arterial $\mathrm{pH}$, oxygen partial pressure $\left(\mathrm{PaO}_{2}\right)$ and arterial bicarbonate concentration $\left(\mathrm{HCO}_{3}^{-}\right)$in horses treated with detomidine in combination with saline (D/SAL), morphine (D/MORPH) or methadone (D/METH).

\begin{tabular}{|c|c|c|c|c|c|c|c|}
\hline & \multicolumn{7}{|c|}{ Time after treatment (min) } \\
\hline & Baseline & 5 & 15 & 30 & 60 & 90 & 120 \\
\hline \multicolumn{8}{|c|}{$\mathrm{PaCO}_{2}(\mathrm{mmHg})$} \\
\hline $\mathrm{D} / \mathrm{SAL}$ & $33 \pm 2$ & $33 \pm 1$ & $36 \pm 1$ & $34 \pm 2$ & $36 \pm 3$ & $37 \pm 2$ & $38 \pm 1$ \\
\hline D/MORPH & $32 \pm 3$ & $36 \pm 4$ & $36 \pm 3$ & $35 \pm 5$ & $35 \pm 3$ & $34 \pm 2$ & $35 \pm 3$ \\
\hline D/METH & $33 \pm 5$ & $34 \pm 7$ & $35 \pm 3$ & $35 \pm 5$ & $35 \pm 1$ & $33 \pm 1$ & $35 \pm 1$ \\
\hline \multicolumn{8}{|l|}{ pH (units) } \\
\hline $\mathrm{D} / \mathrm{SAL}$ & $7.45 \pm 0.5$ & $7.44 \pm 1$ & $7.43 \pm 0.3$ & $7.44 \pm 0.3$ & $7.46 \pm 1$ & $7.42 \pm 1$ & $7.43 \pm 0.5$ \\
\hline D/MORPH & $7.46 \pm 1$ & $7.43 \pm 0.5$ & $7.44 \pm 0.4$ & $7.44 \pm 1$ & $7.46 \pm 1$ & $7.46 \pm 1$ & $7.46 \pm 1$ \\
\hline D/METH & $7.47 \pm 1$ & $7.45 \pm 0.1$ & $7.48 \pm 1$ & $7.46 \pm 1$ & $7.45 \pm 1$ & $7.44 \pm 1$ & $7.45 \pm 0.5$ \\
\hline \multicolumn{8}{|c|}{$\mathrm{HCO}_{3}^{-}(\mathrm{mmol} / \mathrm{L})$} \\
\hline $\mathrm{D} / \mathrm{SAL}$ & $22 \pm 0.5$ & $21 \pm 0.5$ & $23 \pm 1$ & $22 \pm 1$ & $25 \pm 1$ & $23 \pm 1$ & $24 \pm 2$ \\
\hline D/MORPH & $22 \pm 1$ & $24 \pm 2$ & $23 \pm 3$ & $23 \pm 3$ & $25 \pm 2$ & $24 \pm 1$ & $24 \pm 2$ \\
\hline D/METH & $26 \pm 2$ & $24 \pm 4$ & $24 \pm 3$ & $25 \pm 4$ & $24 \pm 1$ & $22 \pm 1$ & $23 \pm 1$ \\
\hline \multicolumn{8}{|c|}{$\mathrm{PaO}_{2}(\mathrm{mmHg})$} \\
\hline $\mathrm{D} / \mathrm{SAL}$ & $100 \pm 4$ & $98 \pm 5$ & $97 \pm 2$ & $99 \pm 4$ & $99 \pm 8$ & $98 \pm 3$ & $100 \pm 5$ \\
\hline D/MORPH & $101 \pm 2$ & $97 \pm 4$ & $97 \pm 6$ & $97 \pm 4$ & $98 \pm 5$ & $99 \pm 9$ & $98 \pm 4$ \\
\hline D/METH & $98 \pm 4$ & $100 \pm 7$ & $97 \pm 4$ & $97 \pm 6$ & $98 \pm 5$ & $99 \pm 9$ & $97 \pm 6$ \\
\hline
\end{tabular}

Note: Data are expressed as mean \pm standard deviation (SD).

\section{Discussion}

The results of this study confirm previous observations of classic sedation signs in horses which include ataxia, lowering of the head, drooping of the lower lip, and eyelid ptosis (VALVERDE, 2010). Furthermore, head height is an important external sign of sedation in horses and is used as a clinical parameter for evaluating the effectiveness of a sedative drug (KAUKINEN et al., 2011). In the current study, all the treatments showed peak sedation at $5 \mathrm{~min}$ after the onset of the study. As expected, sedation began quickly due to the fast activation of the presynaptic $\alpha_{2}$ receptors after IV detomidine administration (MAMA et al., 2009). Earlier studies showed the deepest degree of sedation to be between four and 10 mins after IV administration of detomidine and the duration of sedation to be approximately 60 to 90 mins (FREEMAN; ENGLAND, 2000; GRIMSRUD et al., 2009).

However, unlike earlier studies (CLARKE; PATON, 1998; VAN DIJK et al., 2003), the sedative effect was not increased or prolonged by the addition of opioids to detomidine. This result supports the findings of Love et al. (2011) who reported no increase in the degree of sedation after the addition of buprenorphine to detomidine $(10 \mu \mathrm{g} /$ $\mathrm{kg}$ ) in horses. These findings may be related to the central excitatory effects that can be induced by mu agonists, such as morphine and methadone. Studies in cats, rats and horses suggest that the activity produced by the mu agonist is a result of an increase in central dopamine neurotransmission (DHASMANA et al., 1972; DI CHIARA; 
IMPERATO, 1988). Although dopamine is believed to be the primary neurotransmitter involved in opioidergic pathways, other neurotransmitters have been implicated both directly and indirectly (MAMA et al., 1993). Acetylcholine (ACH), norepinephrine (NE) and gamma amino butyric acid (GABA) involvement have been associated with opioidergic neurotransmission in different regions of the rat brain (AUSTIN; KALIVAS, 1989; HEIJNA et al., 1990). Thus, as the $\alpha_{2-}$ agonists act in part by modulation of central NE release, in combination with opioids the behavioral excitatory response can be reduced. However, the level of the sedative effect may be impaired (LOVE et al., 2011).

Several studies have described the dose-related adverse effects of morphine in equines. Dysphoria, followed by euphoria was reported when $0.12 \mathrm{mg}$ / $\mathrm{kg}$ was used (MUIR et al., 1978) while higher doses $(0.66$ to $0.75 \mathrm{mg} / \mathrm{kg}$ ) produced increased locomotor activity, restlessness, pacing, body swing, boxwalking and pawing (KALPRAVIDH et al., 1984). In agreement with previous studies that reported muscle twitching and excited behavior after opioid administration in equines (KALPRAVIDH et al., 1984; LOVE et al., 2011), in the present study, two morphine treated horses demonstrated muscular tremors, and one of these horses exhibited signs of dysphoria at $120 \mathrm{~min}$ after sedation. This result suggests that co-administration of detomidine most likely obscures the stimulant effects of morphine, while its plasma concentration is sufficient to produce a central depressor effect.

All three sedative treatments resulted in a decrease in the horses' reactions to oral stimuli. However, the addition of morphine or methadone did not facilitate access to the oral cavity. Similar results were reported with xylazine alone or in combination with butorphanol in standing horses submitted to dental float insertion (WAGNER et al., 2011). In contrast, clinical studies have reported a pronounced degree of sedation and analgesia during standing surgery in horses, with the addition of opioids, such as butorphanol, morphine and buprenorphine, to the $\alpha_{2}$-agonists (VAN DIJK et al., 2003; BENREDOUANE et al., 2011). These differences suggest that the addition of an opioid to detomidine may confer more benefit when the horse is undergoing a surgical procedure and associated nociception (LOVE et al., 2011).

The effect of detomidine on heart rate is well documented (FREEMAN; ENGLAND, 2000; NANNARONE et al., 2007). As expected, a reduction in heart rate was initially observed after all the treatments, although the values were within physiological range. Nevertheless, a significant decrease was detected only at $5 \mathrm{~min}$ after the administration of detomidine/saline. This result supports the findings of Love et al. (2011) who reported minimal changes in HR following the administration of $10 \mu \mathrm{g} / \mathrm{kg}$ of detomidine to horses. Furthermore, several studies have found no significant changes in heart rate after opioid treatment in healthy horses (VALVERDE, 2010; LOVE et al., 2011)

The biphasic effect on blood pressure is a common finding after $\alpha_{2}$-agonist administration, resulting in initial hypertension, followed by decreased sympathetic discharge (YAMASHITA et al., 2000; BUHL et al., 2007). In the current study, all the treatments demonstrated an initial increase in MAP, which returned to baseline values after the $\mathrm{D} / \mathrm{SAL}$ and D/METH treatments, but not after the D/MORPH treatment. The increase in MAP was probably caused by the rise in vascular resistance from postsynaptic $\alpha-2 \mathrm{~B}$ stimulation, as described in earlier studies (WAGNER et al., 1991; BUHL et al., 2007). Moreover, some studies have shown an increase in heart rate and blood pressure after IV morphine administration to pain-free horses (MUIR et al., 1978; KALPRAVIDH et al., 1984). The sympathetic response induced by opioid drugs is related to central nervous stimulation. ${ }^{17}$ In the present study, although the mean blood pressure was higher in the D/MORPH than in the D/SAL group between 75 and 120 mins, hypertension was observed in only one horse that showed signs of behavioral excitement, suggesting that the reduction 
of the detomidine sedation effect allowed for the perception of the central stimulation produced by morphine.

Detomidine has little effect on pulmonary function when administered at doses of 10 to $20 \mu \mathrm{g} /$ kg(FREEMAN; ENGLAND, 2000; NANNARONE et al., 2007). In a previous study, intravenously administered detomidine $(20 \mu \mathrm{g} / \mathrm{kg})$ resulted in a significant but stable decrease in the respiratory rate compared to unsedated horses (WAGNER et al., 1991).

Opioids, principally mu agonists, may produce respiratory depression. Morphine, at doses below $0.05 \mathrm{mg} / \mathrm{kg}$, usually reduces the respiratory rate, while doses higher than $0.1 \mathrm{mg} / \mathrm{kg}$ may induce hyperventilation due to excitatory effects on the central nervous system (MUIR et al., 1978). Kalpravidh et al. (1984) reported a marked increase in respiratory rate after morphine administration of $0.66 \mathrm{mg} / \mathrm{kg}$ in horses. In contrast, Figueiredo et al. (2012) found minimal changes in respiratory rate, arterial $\mathrm{pH}$ and blood gas variables, following IV or IM morphine at a dose of $0.05-0.1 \mathrm{mg} / \mathrm{kg}$.

There are limited reports on the respiratory effects of methadone alone or in combination with $\alpha_{2}$-agonists in horses. Oral methadone $(0.1,0.2$ and $0.4 \mathrm{mgkg}$ ) did not change the respiratory rate in adult horses (LINARDI et al., 2009). Similarly, minimal changes in pulmonary function were observed following IV methadone treatment $(0.15$ $\mathrm{mg} \mathrm{kg}$ ) in horses (LINARDI et al., 2012). In the current study, mild changes were detected in relation to respiratory rate, arterial $\mathrm{pH}$ and blood gas status, suggesting that all the treatments provided stable respiratory function.

\section{Conclusion}

All the treatments in this study provided mild cardiopulmonary changes and reduced the horses' reactions to oral stimuli. However the addition of morphine or methadone to detomidine appears not to improve the sedative degree in horses submitted to experimental oral stimuli.

\section{References}

AUSTIN, M. C.; KALIVAS, P. W. Blockade of enkephalinergic and GABAergic mediated locomotion in the nucleus accumbens by muscimol in the ventral pallidum. Japonese Journal of Pharmacology, Tokyo, v. 50, n. 4, p. 487-490, aug. 1989.

BENREDOUANE, K.; RINGER, S. K.; FOUREL, I.; LEPAGE, O. M.; PORTIER, K. G.; BETTSCHARTWOLFENSBERGER, R. Comparison of xylazinebutorphanol and xylazine-morphine-ketamine infusions in horses undergoing a standing surgery. The Veterinary Record, London, v. 169, n. 14, p. 364-366, oct. 2011.

BRYANT, C. E.; ENGLAND, G. C.; CLARKE, K. W. Comparison of the sedative effects of medetomidine and xylazine in horses. The Veterinary Record, London, v. 129, n. 19, p. 421-423, nov. 1991.

BUHL, R.; ERSBØLL, A. K.; LARSEN, N. H.; ERIKSEN, L.; KOCH, J. The effects of detomidine, romifidine or acepromazine on echocardiographic measurements and cardiac function in normal horses. Veterinary Anaesthesia and Analgesia, Oxford, v. 34, n. 1, p. 1-8, jan. 2007.

CLARKE, K. W.; PATON, B. S. Combined use of detomidine with opiates in the horse. Equine Veterinary Journal, Suffolk, v. 20, n. 5, p. 331-334, sept. 1988.

CORletto, F.; RAISIS, A. A.; BREARley, J. C. Comparison of morphine and butorphanol as preanaesthetic agents in combination with romifidine for field castration in ponies. Veterinary Anaesthesia and Analgesia, Oxford, v. 32, n. 1, p. 16-22, jan. 2005.

DHASMANA, K. M.; DIXIT, K. S.; JAJU, B. P.; GUPTA, M. L. Role of central dopaminergic receptors in manic response of cats to morphine. Psychopharmacologia, Berlin, v. 24, n. 3, p. 380-383, mar. 1972.

DI CHIARA, G.; IMPERATO, A. Opposite effects of mu and kappa opiate agonists on dopamine release in the nucleus accumbens and in the dorsal caudate nucleus of freely moving rats. The Journal of Pharmacology and Experimental Therapheutics, Baltimore, v. 244, n. 3, p. 1067-1080, mar. 1988.

FIGUEIREDO, J. P.; MUIR, W. W.; SAMS, R. Cardiorespiratory, gastrointestinal, and analgesic effects of morphine sulfate in conscious healthy horses. American Journal of Veterinary Research, Chicago, v. 73, n. 6, p. 799-808, jun. 2012. 
FREEMAN, S. L.; ENGLAND, G. C. Investigation of romifidine and detomidine for the clinical sedation of horses. The Veterinary Record, London, v. 147, n. 18, p. 507-511, oct. 2000.

GRIMSRUD, K. N.; MAMA, K. R.; THOMASY, S. M.; STANLEY, S. D. Pharmacokinetics of detomidine and its metabolites following intravenous and intramuscular administration in horses. Equine Veterinary Journal, Suffolk, v. 41, n. 4, p. 361-365, apr. 2009.

HEIJNA, M. H.; SCHOFFELMEER, A. N.; MULDER, A. H. Regional differences in opioid receptor-mediated inhibition of dopamine and acetylcholine release in the rat brain. Progress in Clinical and Biological Research, New York, v. 328, n. 1, p. 299-302, 1990.

KALPRAVIDH, M.; LUMB, W. V.; WRIGHT, M.; HEATH, R. B. Effects of butorphanol, flunixin, levorphanol, morphine, and xylazine in ponies. American Journal of Veterinary Research, Chicago, v. 45, n. 2, p. 217-223, feb. 1984.

KAUKINEN, H.; ASPEGRÉN, J.; HYYPPÄ, S.; TAMM, L.; SALONEN, J. S. Bioavailability of detomidine administered sublingually to horses as an oromucosal gel. Journal of Veterinary Pharmacology and Therapeutics, Oxford, v. 34, n. 1, p. 76-81, feb. 2011.

LINARDI, R. L.; STOKES, A. M.; BARKER, S. A.; SHORT, C.; HOSGOOD, G.; NATALINI, C. C. Pharmacokinetics of the injectable formulation of methadone hydrochloride administered orally in horses. Journal of Veterinary Pharmacology and Therapeutics, Oxford, v. 32, n. 5, p. 492-497, oct. 2009.

LINARDI, R. L.; STOKES, A. M.; KEOWEN, M. L.; BARKER, S. A.; HOSGOOD, G.; SHORT, C.; Bioavailability and pharmacokinetics of oral and injectable formulations of methadone after intravenous, oral, and intragastric administration in horses. American Journal of Veterinary Research, Chicago, v. 73, n. 2, p. 290-295, feb. 2012.

LOVE, E. J.; TAYLOR, P. M.; MURRELL, J.; WHAY, H. R.; WATERMAN-PEARSON, A. E. Assessment of the sedative effects of buprenorphine administered with $10 \mu \mathrm{g} / \mathrm{kg}$ detomidine in horses. The Veterinary Record, London, v. 168, n. 14, p. 379-383, apr. 2011.

MAMA, K. R.; GRIMSRUD, K.; SNELL, T.; STANLEY, S. Plasma concentrations, behavioural and physiological effects following intravenous and intramuscular detomidine in horses. Equine Veterinary Journal, Suffolk, v. 41, n. 8, p. 772-777, nov. 2009.

MAMA, K. R.; PASCOE, P. J.; STEFFEY, E. P. Evaluation of the interaction of mu and kappa opioid agonists on locomotor behavior in the horse. Canadian Journal of Veterinary Research, Ottawa, v. 57, n. 2, p. 106-109, apr. 1993.

MUIR, W. W.; SKARDA, R. T.; SHEEHAN, W. C. Cardiopulmonary effects of narcotic agonists and a partial agonist in horses. American Journal of Veterinary Research, Chicago, v. 39, n. 10, p. 1632-1635, oct. 1978.

NANNARONE, S.; GIALLETTI, R.; VESCHINI, I.; BUFALARI, A.; MORICONI, F. The use of alpha-2 agonists in the equine practice: comparison between three molecules. Veterinary Research Communications, Dordrecht, v. 31, p. 309-312, aug. 2007. Supplement 1.

ROBERTSON, S. A. Standing sedation and pain management for ophthalmic patients. The Veterinary Clinics of North American. Equine Practice, Philadelphia, v. 20, n. 2, p. 485-497, aug. 2004.

ROHRBACH, H.; KORPIVAARA, T.; SCHATZMANN, U.; SPADAVECCHIA, C. Comparison of the effects of the alpha-2 agonists detomidine, romifidine and xylazine on nociceptive withdrawal reflex and temporal summation in horses. Veterinary Anaesthesia and Analgesia, Oxford, v. 36, n. 4, p. 384-395, jul. 2009.

ROSCOE, M. P. Avaliação de seis protocolos de sedação para procedimentos odontológicos em equinos. 2007. Dissertação (Mestrado em Medicina Veterinária) - Curso de Pós-Graduação em Ciência Animal. Universidade Federal de Minas Gerais, Belo Horizonte.

SOLANO, A. M.; VALVERDE, A.; DESROCHERS, A.; NYKAMP, S.; BOURE, L. P. Behavioural and cardiorespiratory effects of a constant rate infusion of medetomidine and morphine for sedation during standing laparoscopy in horses. Equine Veterinary Journal, Suffolk, v. 41, n. 2, p. 153-159, feb. 2009.

VALVERDE, A. Alpha-2 agonists as pain therapy in horses. The Veterinary Clinics of North American. Equine Practice, Philadelphia, v. 26, n. 3, p. 515-532, dec. 2010.

VAN DIJK, P.; LANKVELD, D. P.; RIJKENHUIZEN, A. B.; JONKER, F. H. Hormonal, metabolic and physiological effects of laparoscopic surgery using a detomidine-buprenorphine combination in standing horses. Veterinary Anaesthesia and Analgesia, Oxford, v. 30, n. 2, p. 72-80, apr. 2003.

WAGNER, A. E.; MAMA, K. R.; CONTINO, E. K.; FERRIS, D. J.; KAWCAK, C. E. Evaluation of sedation and analgesia in standing horses after administration of xylazine, butorphanol, and subanesthetic doses of ketamine. Journal of the American Veterinary Medical Association, New York, v. 238, n. 12, p. 1629-1633, 2011. 
WAGNER, A. E.; MUIR, W. W.; HINCHCLIFF, K. W. Cardiovascular effects of xylazine and detomidine in horses. American Journal of Veterinary Research, Chicago, v. 52, n. 5, p. 651-657, 1991.
YAMASHITA, K.; TSUBAKISHITA, S.; FUTAOK, S.; UEDA, I.; HAMAGUCHI, H.; SENO, T.; KATOH, S.; IZUMISAWA, Y.; KOTANI, T.; MUIR, W. W. Cardiovascular effects of medetomidine, detomidine and xylazine in horses. Journal of Veterinary Medical Science, Tokyo, v. 62, n. 10, p. 1025-1032, 2000. 
